\title{
Myxobolus species (Myxozoa), parasites of fishes in the Okavango River and Delta, Botswana, including descriptions of two new species
}

\author{
Cecilé C. Reed, Linda Basson and Liesl L. Van As
}

Department of Zoology and Entomology, University of the Free State, P.O. Box 339, Bloemfontein, 9300, South Africa

Key words: Myxozoa, Myxobolus, new species, taxonomy, fish parasites, Botswana

\begin{abstract}
Fieldwork was conducted in 1998 and 1999 in the Okavango River and Delta and a total of 275 fishes representing 31 species were examined for the presence of myxosporean parasites. A total of seven myxosporeans of the genus Myxobolus Bütschli, 1882 were found infecting the fishes. Two new species namely Myxobolus etsatsaensis sp. n. from Barbus thamalakanensis Fowler, 1935 and M. paludinosus sp. n. from Barbus paludinosus Peters, 1852 are described. Myxobolus africanus Fomena, Bouix et Birgi, 1985, M. camerounensis Fomena, Marqués et Bouix, 1993, M. hydrocyni Kostoïngue et Toguebaye, 1994, M. nyongana (Fomena, Bouix et Birgi, 1985) and M. tilapiae Abolarin, 1974 are recorded for the first time in Botswana and descriptions of these species are provided.
\end{abstract}

Myxosporean research in Africa dates back to the late $19^{\text {th }}$ century with Gurley (1893) being one of the earliest authors referring to the continent. The African continent boasts over a 100 myxosporean species from freshwater, brackish and marine fishes of which 84 infect primarily freshwater fishes (Fomena and Bouix $1997)$ and this number is continuously growing. When comparing the known African myxosporeans to the more than 1,300 species described worldwide, it is evident that for a huge continent with such high fish diversity, a large gap exists in the knowledge on the occurrence and distribution of these parasites.

In southern Africa little research has been conducted on myxosporean parasites of fish, with only a few publications appearing largely on marine myxosporeans from South Africa such as Fantham (1919, 1930), Gilchrist (1924), Paperna et al. (1987) and Ali (2000). The only record ever of a freshwater myxosporean from Botswana is that of Peters (1971), commenting on Boulenger (1911) who published a brief note on an anabantid showing a mouth-brooding habit from the Okavango River. According to Peters (1971), Boulenger commented the following: "On examining a female, about 5 ins. long, I found seven or eight eggs about one line in diameter, closely packed on each side in a cavity behind the gills, entirely covered by operculum". While conducting comparative studies on the ethology of African Anabantidae, Peters (1971) examined the rounded bodies, which did look like eggs, and discovered that they were in fact mature plasmodia from a myxosporean infection.

Now, 30 years later, the results of the first investigation into myxosporean parasites infecting fishes in the Okavango River and Delta are presented. Over a period of two years (1998 and 1999) a total of
275 fishes from the Okavango Delta, representing 31 species and 9 families were examined for the presence of myxosporean parasites. This paper reports on the occurrence of seven myxosporeans of the genus Myxobolus Bütschli, 1882 found infecting eight different host fish species in the Okavango River and Delta, Botswana.

\section{MATERIALS AND METHODS}

Fieldwork was conducted in the Okavango River and Delta in Botswana during June and July in both 1998 and 1999. Fishes were collected using hand nets, cast nets, sein nets and a series of gill nets from mainstream and lagoon environments. Live fishes were taken back to a mobile field laboratory where they were kept in aerated aquaria. The fishes were identified and anaesthetised with a dosage of benzocaine sufficient to kill them. Standard techniques when working with myxosporeans requires the observation and photography of live spores, but due to the isolated collection localities mature myxosporean spores found in plasmodia were fixed in $10 \%$ buffered neutral formalin. Due to the formalin fixation of the spores, some structures could not be observed in the material, such as intercapsular appendices and iodinophilous vacuoles. Since most of the plasmodia in the present study were very small, spores from a number of plasmodia were measured. However, in all cases the plasmodia were obtained from the same host specimen. The fixed spores were photographed using a Zeiss Axiophot microscope with differential interference contrast on a layer of $0.5 \%$ non-nutrient agar and were measured according to the guidelines provided by Lom and Arthur (1989). Minimum and maximum values of spore measurements are provided in micrometres $(\mu \mathrm{m})$, followed in parentheses by the arithmetic mean and standard deviation. Permanent preparations were made by impregnating myxosporean spores with silver nitrate. Myxoboli described in the 
present study have only been compared to African species, as the Okavango River, which forms part of the Upper Zambesi System, is a pristine habitat with no introductions or translocations of fishes. All reference material, in the form of fixed spores or silver-impregnated smears of spores has been deposited in the parasite collection of the Department of Zoology and Entomology, University of the Free State, Bloemfontein, South Africa where it has been allocated a reference number. Type material has been deposited in the collection of the National Museum, Bloemfontein (South Africa) where it has been allocated a NMBP number indicating its place in the National Museum Bloemfontein's Parasite collection.

\section{RESULTS}

Myxobolus africanus Fomena, Bouix et Birgi, 1985, M. camerounensis Fomena, Marqués et Bouix, 1993, M. hydrocyni Kostoïngue et Toguebaye, 1994, $M$. nyongana (Fomena, Bouix et Birgi, 1985) and $M$. tilapiae Abolarin, 1974 were all collected for the first time in Botswana. Two species that did not conform to the description of any known African species were also collected and are subsequently described as $M$. etsatsaensis sp. n. and M. paludinosus sp. n.

Myxobolus africanus Fomena, Bouix et Birgi, 1985 Figs. 1, 8, 15

Description of vegetative stages: Only sporogonic plasmodia found within secondary gill lamella. Polysporous plasmodia spherical, whitish, $1 \mathrm{~mm}$ in diameter.

Description of spores (based on 11 spores from fully mature plasmodia): In valvular view spore body ovoid with anterior end pointed, 15-17 (16.7 \pm 0.67$)$ in length. Widest region of spore observed towards posterior part of polar capsules, 4-6 (5.4 \pm 0.45$)$ in width. Two shell valves visible with prominent sutural ridge. Shell valves smooth. Two polar capsules of equal size situated in anterior end of spore. Polar capsules 3.0-5.0 (4.0 \pm 0.15$)$ long $\times 1.5-2(2.0 \pm 0.15)$ wide. Four to six coils of polar filament visible.

H o s t: Hepsetus odoe (Bloch, 1794).

Site of infection: Gills, fins.

L o c a 1 i t y : Samochima, Mokoro and Thoage Lagoons in the Okavango River and Delta (Botswana).

M a t e r i a 1 e x a m i n e d : 1999/08/13-02 (spores fixed in $10 \%$ buffered neutral formalin).

Remarks: The distinct morphological characteristic of having one polar capsule discharging laterally as well as the spore dimensions of these spores match those of Myxobolus africanus. Fomena et al. (1985) originally described this myxosporean species from Cameroon, also from the African pike, Hepsetus odoe. The occurrence of this species in the Okavango River and Delta in Botswana is a new geographic record for the species.

\section{Myxobolus camerounensis Fomena, Marqués et Bouix, 1993 \\ Figs. 2, 9}

Description of vegetative stages: Sporogonic plasmodia found in epithelium of buccal cavity and gill arch of host. Polysporous plasmodia, spherical to elongate, whitish, 1-3 mm in length.

Description of spores (based on 10 spores from mature plasmodia): In valvular view, spore body slightly elongate to ovoid with anterior end bluntly pointed and posterior end rounded, 16.2-17.5 (16.7 \pm 0.5 ) in length. Widest region of spore observed behind posterior ends of polar capsules, 11.2-12.5 (11.6 \pm 0.60$)$ in width. Two smooth shell valves visible with narrow sutural ridge passing along edge of spore. Two rounded pyriform polar capsules of equal size situated in anterior part of spore measuring 6.8-7.5 (7.3 \pm 0.32$)$ long $\times 3$ $3.8(3.6 \pm 0.42)$ wide. Five to six coils visible in polar filament.

H o s t s : Oreochromis andersonii (Castelnau, 1861), Tilapia ruweti (Poll et Thys van den Audenaerde, 1965).

Site of infection: Gill arch and buccal cavity.

L o c a 1 i t y : Xaro and Etsatsa Mainstreams in the Okavango River and Delta (Botswana).

M a t e r i a 1 e x a m in e d : 1998/08/09-04 (spores from $O$. andersonii fixed in $10 \%$ buffered neutral formalin) and 1998/07/24-25 (spores from T. ruweti fixed in $10 \%$ buffered neutral formalin).

Remarks: This species conforms to the description of $M$. camerounensis originally described by Fomena et al. (1993) from the gills of Oreochromis niloticus in Cameroon. There are currently 11 Myxobolus species parasitising cichlids in Africa (Baker 1963, Abolarin 1974, Landsberg 1985, Faisal and Shalaby 1987, Sakiti et al. 1991, Fomena et al. 1993). Myxobolus camerounensis is most similar to $M$. homeosporus Baker, 1963, but differs in having ovoid spores that are not slightly elongated. The polar capsules of $M$. homeosporus are also slightly smaller and thus although the spore dimensions are similar, the polar capsules of $M$. camerounensis take up more space in the spore body.

The presence of $M$. camerounensis on the gill arches and buccal cavities of $O$. andersonii and $T$. ruweti provide two new host records for this myxosporean species. These records increase the number of fish hosts infected by $M$. camerounensis to three, all of which are cichlids. The presence of this species in the Okavango River and Delta in Botswana is also a new geographic record for the species.

\section{Myxobolus hydrocyni Kostoïngue et Toguebaye, 1994 Figs. 3, 10, 16}

Description of vegetative stages: Sporogonic plasmodia found within epithelial cells of gill operculum as well as in gill arch cartilage. Polysporous plasmodia spherical, whitish, $1 \mathrm{~mm}$ in diameter. 

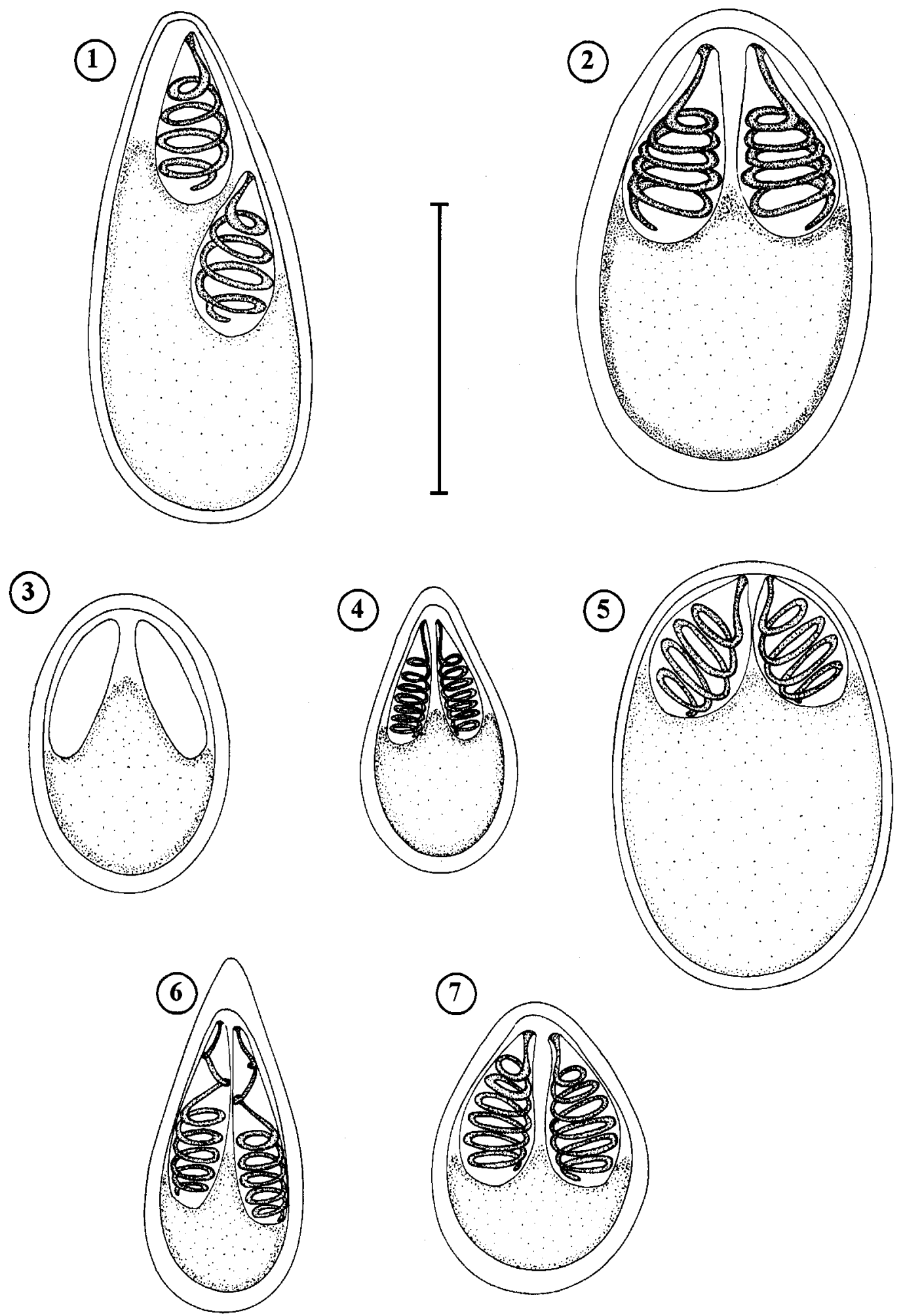

Figs. 1-7. Myxobolus Bütschli, 1882 species collected from the Okavango River and Delta, Botswana; microscope projection drawings of formalin-fixed spores. Fig. 1. Myxobolus africanus Fomena, Bouix et Birgi, 1985 from the gills and fins of Hepsetus odoe (Bloch, 1794). Fig. 2. Myxobolus camerounensis Fomena, Marqués et Bouix, 1993 from the gill arch of Oreochromis andersonii (Castelnau, 1861). Fig. 3. Myxobolus hydrocyni Kostoïngue et Toguebaye, 1994 from the gills of Hydrocynus vittatus Castelnau, 1861. Fig. 4. Myxobolus nyongana (Fomena, Bouix et Birgi, 1985) from the gills of Barbus poechii Steindachner, 1911. Fig. 5. Myxobolus cf. tilapiae Abolarin, 1974 from the buccal cavity of Tilapia rendalli rendalli (Boulenger, 1896). Fig. 6. Myxobolus etsatsaensis sp. n. from the gills of Barbus thamalakanensis Fowler, 1935. Fig. 7. Myxobolus paludinosus sp. n. from the gills of Barbus paludinosus Peters, 1852. Scale bar $=10 \mu \mathrm{m}$. 
Description of spores (based on 10 spores from fully mature plasmodia): Spore body ovoid in valvular view, with anterior and posterior end rounded, 8.7-10.1 (9.9 \pm 0.38 ) in length. Widest region of spore observed towards posterior ends of polar capsules, 6.2-7.5 (7.2 \pm 0.39 ) in width. Two shell valves visible with sutural ridge passing around edge of spore. Shell valves smooth with two slender polar capsules of equal size situated anteriorly, 3.7-5 (4.5 \pm 0.63$)$ long $\times 1.0-1.2(1.2 \pm 0.13)$ wide. Number of coils in polar filament within polar capsules difficult to observe.

H o s t: Hydrocynus vittatus Castelnau, 1861.

Site of infection: Gill operculum and gill arch.

L o c a 1 i t y : Xaro and Etsatsa mainstreams, Okavango River and Delta (Botswana).

M a t e ri a 1 e x a m in ed: No. 1999/07/08-14 (spores fixed in $10 \%$ buffered neutral formalin).

Remarks: The overall spore morphology and dimensions of this species conforms to that of Myxobolus hydrocyni originally described from the gills of Hydrocynus forskalii in Chad by Kostoïngue and Toguebaye (1994). Myxobolus hydrocyni is similar in shape to M. amieti Fomena, Bouix et Birgi, 1985 which was found in various organs of Ctenopoma nanum by Fomena et al. (1985). These species both have two polar capsules that do not lie parallel to each other, but only converge in the anterior half of the spore. The spores of M. hydrocyni differ in being more spherical than the slender, more elongated spores of $M$. amieti. The polar capsules of $M$. amieti extend through more than half of the spore body, which differs from those of $M$. hydrocyni that reach only the centre of the spore. Having a similar spore body shape to $M$. noukoueensis Sakiti, Blanc, Marqués et Bouix, 1991, M. hydrocyni is distinct in having polar capsules that extend to the centre of the spore and are neither short nor pyriform.

Myxobolus hydrocyni is recorded for the first time in Botswana.

Myxobolus nyongana (Fomena, Bouix et Birgi, 1985) Fomena et Bouix, 1997

Figs. 4, 11, 17

Syn.: Myxobolus barbi Fomena, Bouix et Birgi, 1985

Description of vegetative stages: Sporogonic plasmodia found within secondary gill lamellae. Polysporous plasmodia small and rounded, whitish, $1 \mathrm{~mm}$ in diameter.

Description of spores (based on 12 spores from fully mature plasmodia): In valvular view, spore body is teardrop-shaped to ovoid with anterior tapering to blunt point, 11.0-11.2 (11.2 \pm 0.26$)$ in length. Widest region of spore observed towards centre of sporoplasm, 6.1-7.0 $(6.5 \pm 0.31)$ in width. Two smooth shell valves visible as well as narrow sutural ridge, which is slightly broader at posterior end of spore. Two polar capsules of occasionally unequal size situated in anterior part of spore,
3.0-5.5 (4.4 \pm 0.79$)$ long $\times 1.25-2.5(1.6 \pm 0.44)$ wide. Polar filament coils seven times within polar capsules.

H o s t: Barbus poechii Steindachner, 1911.

$\mathrm{S}$ ite of infection: Secondary gill lamellae.

L o c a 1 i t y : Etsatsa Mainstream, Okavango River and Delta (Botswana).

M a t e r i a 1 e x a m in ed : 1999/07/08-13 (spores fixed in $10 \%$ buffered neutral formalin).

Remarks: The morphology of these spores conforms to the description of $M$. nyongana, which was originally described from the gills of Barbus jae by Fomena et al. (1985). Other Myxobolus species found in Barbus hosts in Africa are M. njinei Fomena, Bouix et Birgi, 1985, M. nkolyaensis Fomena et Bouix, 1994 and M. oloi Fomena et Bouix, 1994. Myxobolus nyongana differs from these three in the following ways. Myxobolus njinei has a spherical to ovoid spore with rounded posterior and anterior ends. The spores are also much larger than the spores of $M$. nyongana. Myxobolus nkolyaensis has an almost spherical spore with subspherical polar capsules, as well as a reduced sporoplasm and occasionally a third polar capsule in the spore body (Fomena and Bouix 1997). Myxobolus oloi has an oval spore body with asymmetric polar capsules containing four to five coils in the polar filaments and these spores are also smaller in overall dimension to that of $M$. nyongana.

This represents both a new geographical and host record for M. nyongana found in the gills of B. poechii in Botswana.

Myxobolus cf. tilapiae Abolarin, 1974 Figs. 5, 12, 18

Description of vegetative stages: Sporogonic plasmodia found within the buccal cavity. Polysporous plasmodia, rounded, whitish, $0.5 \mathrm{~mm}$ in diameter.

Description of spores (based on 10 spores from fully mature plasmodia): In valvular view, spore body oblong to oval with anterior and posterior ends bluntly rounded, 14.0-15.5 (15.0 \pm 0.39$)$ in length. Widest region of spore observed towards centre of spore body, 12.0-12.6 $(12.3 \pm 0.27)$ in width. Two smooth shell valves visible with narrow sutural ridge surrounding spore. Two almost spherical to pyriform polar capsules of equal size situated in anterior part of spore, 3.8-5.0 (4.6 \pm 0.55) long $\times 3.0-4.0(3.5 \pm 0.44)$ wide. Polar filaments have four to six coils within polar capsules.

$\mathrm{H}$ o s $\mathrm{t}$ : Tilapia rendalli rendalli (Boulenger, 1896).

L o c a 1 i t y : Samochima Lagoon, Mohembo Floodplains, Okavango River and Delta (Botswana).

Site of infection: Buccal cavity.

M a t e r i a 1 e x a m in ed : 1998/06/21-25 (spores fixed in $10 \%$ buffered neutral formalin).

Remarks: This species is preliminarily identified as Myxobolus cf. tilapiae. Abolarin (1974) provides various different drawings of this species, of which only 

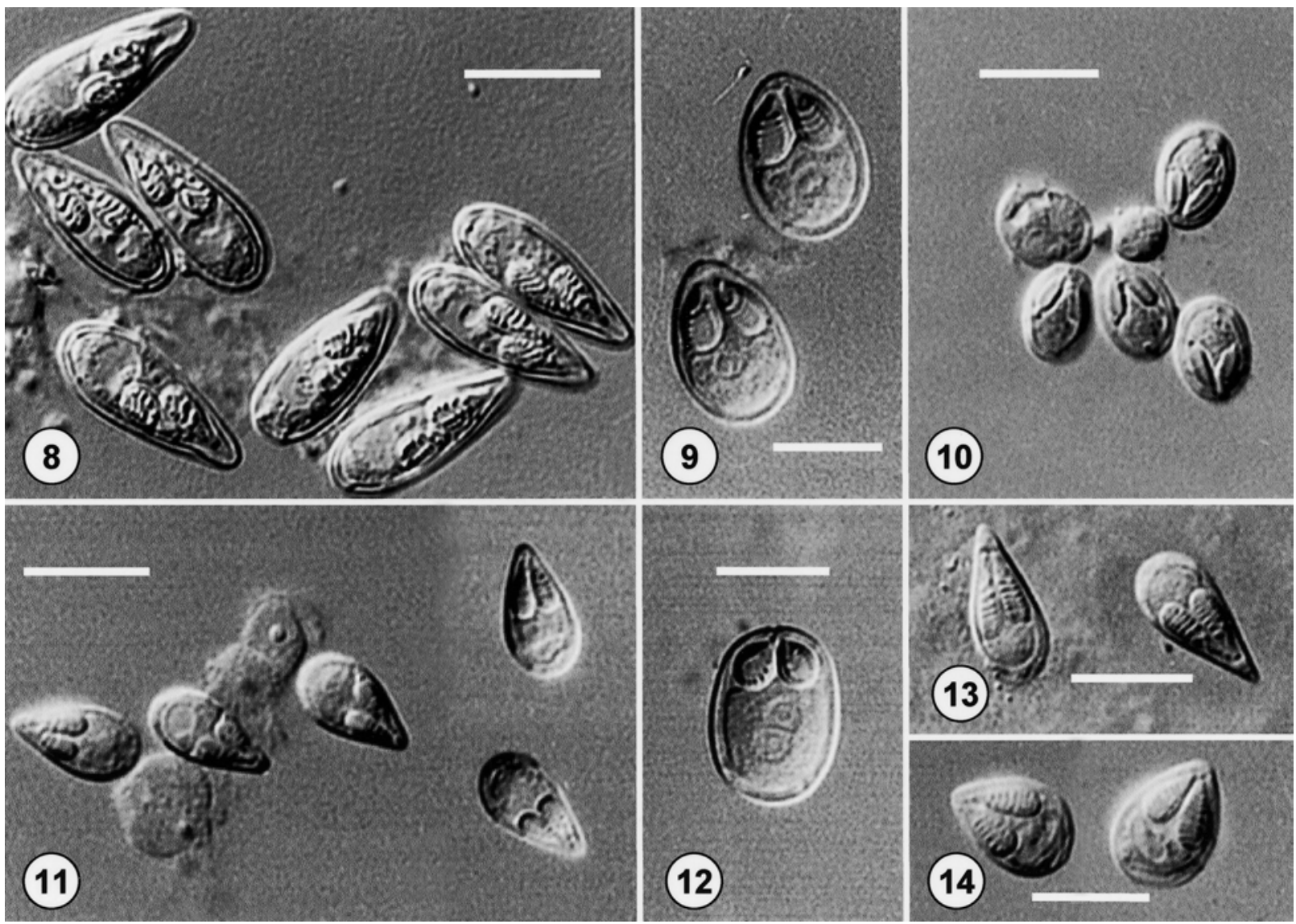

Figs. 8-14. Myxobolus Bütschli, 1882 species collected from the Okavango River and Delta, Botswana; differential interference contrast micrographs of formalin-fixed spores. Fig. 8. Myxobolus africanus Fomena, Bouix et Birgi, 1985 from the gills and fins of Hepsetus odoe (Bloch, 1794). Fig. 9. Myxobolus camerounensis Fomena, Marqués et Bouix, 1993 from the gill arch of Oreochromis andersonii (Castelnau, 1861). Fig. 10. Myxobolus hydrocyni Kostoïngue et Toguebaye, 1994 from the gills of Hydrocynus vittatus Castelnau, 1861. Fig. 11. Myxobolus nyongana (Fomena, Bouix et Birgi, 1985) from the gills of Barbus poechii Steindachner, 1911. Fig. 12. Myxobolus cf. tilapiae Abolarin, 1974 from the buccal cavity of Tilapia rendalli rendalli (Boulenger, 1896). Fig. 13. Myxobolus etsatsaensis sp. n. from the gills of Barbus thamalakanensis Fowler, 1935. Fig. 14. Myxobolus paludinosus sp. n. from the gills of Barbus paludinosus Peters, 1852. Scale bars $=10 \mu \mathrm{m}$.

one resembles the species collected from the Okavango in Botswana. More material from the type host and type locality of $M$. tilapiae would have to be examined to determine whether this species does show such great variation. Myxobolus tilapiae is similar to M. heterosporus (Baker, 1963) type (I) in overall spore shape. The polar capsules of $M$. heterosporus are, however, more pyriform, compared with the more spherical polar capsules of $M$. tilapiae. Myxobolus tilapiae is similar to M. polycentropsi Fomena, Bouix et Birgi, 1985 and $M$. synodonti Fomena, Bouix et Birgi, 1985, parasites of Polycentropsis abbreviata and Synodontis batesii respectively. The former myxosporean species, $M$. polycentropsi, is similar to M. tilapiae in having anterior and posterior ends that are both bluntly rounded. The polar capsules of $M$. polycentropsi are, however, more pyriform (Fomena et al. 1985), compared to the almost spherical ones in M. tilapiae. Finally, Myxobolus synodonti is distinct from $M$. tilapiae in having the anterior end slightly more tapered than the more rounded posterior end. The polar capsules of $M$. synodonti are much larger and elongated, compared to the more spherical polar capsules of $M$. tilapiae.

This represents both a new geographical and host record for M. tilapiae.

\section{Myxobolus etsatsaensis sp. n.}

Figs. 6, 13, 19

Description of vegetative stages: Polysporous plasmodia found within secondary gill lamellae, whitish, very small and rounded.

Description of spores (based on 9 spores from fully mature plasmodia): In valvular view, spores extremely elongated, pyriform to teardrop-shaped, with anterior end tapering sharply to blunt point and posterior end rounded, 12.8-15.0 (13.0 \pm 0.94$)$ in length. Two smooth 


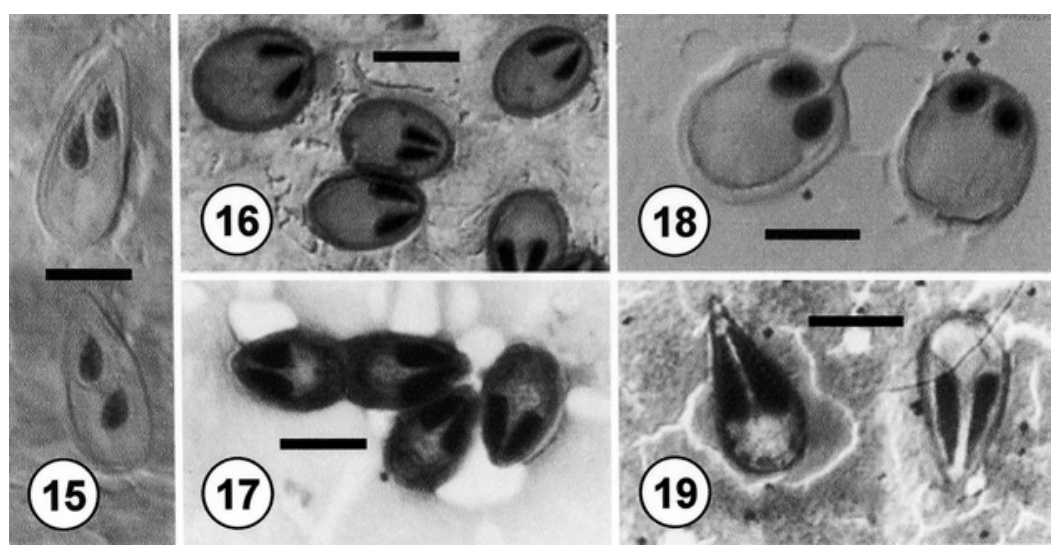

Figs. 15-19. Myxobolus Bütschli, 1882 species collected from the Okavango River and Delta, Botswana; light micrographs of silver-impregnated spores. Fig. 15. Myxobolus africanus Fomena, Bouix et Birgi, 1985 from the gills and fins of Hepsetus odoe (Bloch, 1794). Fig. 16. Myxobolus hydrocyni Kostoïngue et Toguebaye, 1994 from the gills of Hydrocynus vittatus Castelnau, 1861. Fig. 17. Myxobolus nyongana (Fomena, Bouix et Birgi, 1985) from the gills of Barbus poechii Steindachner, 1911. Fig. 18. Myxobolus cf. tilapiae Abolarin, 1974 from the buccal cavity of Tilapia rendalli rendalli (Boulenger, 1896). Fig. 19. Myxobolus etsatsaensis sp. $\mathrm{n}$. from the gills of Barbus thamalakanensis Fowler, 1935. Scale bars $=10 \mu \mathrm{m}$.

shell valves visible. Sutural ridge passes around entire spore and is slightly broader at the posterior end. Two extremely elongated, pyriform polar capsules of unequal length, situated almost parallel to one another in anterior half of spore, 7.0-8.0 (7.5 \pm 0.35) long $\times 1.25-2.5(2.3 \pm$ $0.43)$ wide. Polar filaments contain seven to eight coils in polar capsules. Widest part of spore observed towards posterior of polar capsules, 6.2-8.0 $(6.8 \pm 0.65)$ in width. A small sporoplasm situated in posterior half of spore.

T y p e hos t: Barbus thamalakanensis Fowler, 1935.

$\mathrm{S}$ ite of infection: Secondary gill filaments.

T y p e 1 o c a 1 i t y : Etsatsa Mainstream (18 $51^{\circ}$ '470”'S; $22^{\circ} 25.5^{\prime} 06^{\prime \prime E}$ ) Okavango River and Delta (Botswana).

E t y m o lo g y : Named after the original collection locality of the type host.

T y p e $\mathrm{m}$ a t e $\mathrm{r}$ i a 1 : Holotype, spores in $10 \%$ neutral buffered formalin, 1998/07/25-22A (NMBP 221) and paratypes, spores in $10 \%$ neutral buffered formalin, 1998/07/25-22B (NMBP 274) and 1998/07/25-22C (NMBP 275) in the collection of the National Museum, Bloemfontein, South Africa.

Remarks: As already mentioned, four Myxobolus species, namely M. njinei Fomena, Bouix et Birgi, 1985, $M$. nkolyaensis, $M$. nyongana and $M$. oloi, have been described from Barbus hosts in Africa. Myxobolus etsatsaensis can easily be distinguished from these species because of its characteristic elongated to pyriform spore body. The closest resemblance is with $M$. nyongana described by Fomena et al. (1985) from the gills of Barbus jae. Myxobolus nyongana has a much less extended spore body.

Other morphological similarities are found with $M$. amieti Fomena, Bouix et Birgi, 1985, M. beninensis Sakiti, Blanc, Marqués et Bouix, 1991, M. kriebiensis
Fomena et Bouix, 1994 and a Myxobolus sp. described by Obiekezie and Okaeme (1990). Compared to $M$. amieti, M. etsatsaensis has a very slender spore body that tapers to a sharper degree, forming a narrow anterior end. Furthermore, the polar capsules of $M$. etsatsaensis are more elongated and almost parallel to one another. Myxobolus etsatsaensis differs from $M$. beninensis, found in the gills of Sarotherodon melanotheron by Sakiti et al. (1991), in having a more slender and elongated spore body with a more pointed anterior end. The polar capsules of $M$. beninensis also take up more than half of the spore body, but are slightly more voluminous and are equal in size.

Myxobolus etsatsaensis is very similar to $M$. kriebiensis which was found in various organs of Brycinus longipinnus by Fomena and Bouix (1994), also having very elongated spores. The anterior end of $M$. etsatsaensis is, however, much narrower and tapers to a sharper degree to form a blunt point. The anterior end of $M$. kriebiensis is also narrow, but does not taper to the same degree. The polar capsules of M. kriebiensis are very voluminous and fill just about the entire spore body and have between 19 and 28 coils in the polar filament. The spores of $M$. kriebiensis are also much larger than M. etsatsaensis. Myxobolus etsatsaensis is very similar to a Myxobolus sp. described by Obiekezie and Okaeme (1990) from the kidneys and spleen of various cichlid species, but there are differences in the spore sizes as well as the shell valve thickness.

Myxobolus paludinosus sp. $\mathrm{n}$.

Figs. 7, 14

Description of vegetative stages: Sporogonic plasmodia found within secondary gill lamellae. Polysporous plasmodia, small, rounded, whitish, $0.3 \mathrm{~mm}$ in diameter. 
Description of spores (based on 10 spores from fully mature plasmodia): In valvular view, spore body pyriform to ovoid with anterior end tapering to blunt point and posterior end rounded, 11.2-13.7 (12.0 \pm 0.87$)$ in length. Widest region of spore observed towards posterior ends of polar capsules, 7.5-10.0 (8.6 \pm 0.75$)$ in width. Two smooth shell valves visible with sutural ridge along edge of spore, becoming broader posteriorly. Two polar capsules of equal size situated in anterior end of spore, 5.0-6.8 (5.7 \pm 0.88$)$ long $\times 2.0-2.5$ $(2.4 \pm 0.21)$ wide. Polar filaments have six to seven coils within polar capsules. Sporoplasm situated in posterior half of spore.

Ty p e hos t: Barbus paludinosus Peters, 1852.

Site of infection: Secondary gill lamellae.

T y p e 1 o c a 1 i t y : Etsatsa Mainstream (18 $51^{\prime} 470^{\prime \prime}$; $\left.22^{\circ} 25.5^{\prime} 06^{\prime \prime} \mathrm{E}\right)$, Okavango River and Delta, (Botswana).

E t y m o l o g y : Named after the type host.

T y p e m a te r i a 1 : Holotype, slide 1999/07/05-11 (NMBP

24) and paratypes, spores in $10 \%$ neutral buffered formalin,

1999/07/03-06A (NMBP 25), 1999/07/03-06B (NMBP

220) in the collection of the National Museum, Bloem-

fontein, South Africa.

Remarks: Myxobolus paludinosus does not conform to the description of any other Myxobolus species described in Africa. When compared to those found parasitising Barbus hosts in Africa the following differences can be found. Myxobolus paludinosus is distinct from $M$. njinei described by Fomena et al. (1985), in having an anterior end that tapers to a blunt point and polar capsules that are completely spherical. Myxobolus paludinosus differs from M. nkolyaensis in that the latter species also has an almost spherical shape, with sub-spherical polar capsules. The spore dimensions of $M$. nkolyaensis are smaller than that of $M$. paludinosus. Myxobolus nyongana is similar to $M$. paludinosus in having a spore body that tapers anteriorly to a blunt point with a rounded posterior end, but the spores of $M$. paludinosus are not as slender as those of $M$. nyongana. The polar capsules of $M$. paludinosus do not lie parallel to one another, as in the case of M. nyongana. Myxobolus paludinosus is distinct from $M$. oloi as the latter species has an almost entirely spherical body with two unequal polar capsules.

Myxobolus paludinosus is overall similar to $M$. amieti described by Fomena et al. (1985), but differs, since the latter has a more slender, pyriform spore, with slender polar capsules that take up two thirds of the spore body. Although having a similar spore shape, $M$. paludinosus is distinct from $M$. beninensis in that the latter species has two polar capsules that take up two thirds of the spore body. The spores of $M$. paludinosus are also slightly wider than those of $M$. beninensis. Myxobolus paludinosus is very similar to M. israelensis Landsberg, 1985, in having similar spore dimensions, but the anterior end of the latter species is more rounded than the anterior end of the former species. The polar capsules of $M$. israelensis also take up more space in the spore body, leaving little place for the sporoplasm (Landsberg 1985). Myxobolus paludinosus appears to conform to the description of Myxobolus sp. 2 (Fomena et al. 1985), but there are differences in spore sizes.

Acknowledgements. This study was funded by the Debswana Diamond Company, Botswana as well as the National Research Foundation (NRF) of South Africa. Sincere gratitude to Prof. Iva Dyková from the Institute of Parasitology, Academy of Sciences of the Czech Republic, České Budějovice, Czech Republic, for her assistance during the preparation of the draft copy.

\section{REFERENCES}

ABOLARIN M.O. 1974: Myxobolus tilapiae sp. nov. (Protozoa: Myxosporida) from three species of freshwater tilapia in Nigeria. J. West Afr. Sci. Assoc. 19: 109-114.

ALI M.A. 2000: Ortholinea basma n. sp. (Myxozoa: Myxosporea) from Agile Klipfish Clinus agilis (Teleostei: Clinidae), light and scanning electron microscopy. Eur. J. Protistol. 36: 100-102.

BAKER J.R. 1963: Three new species of Myxosoma (Protozoa: Myxosporidia) from East African freshwater fish. Parasitology 53: 285-292.

BOULENGER G.A. 1911: Parental care in an African fish. The Field 118: 968.

FAISAL M., SHALABY S.I. 1987: Myxosoma tilapiae as a new species (Myxosoma: Myxosporea) in wild Oreochromis niloticus in Lower Egypt. Egypt. J. Vet. Sci. 24: 7386.

FANTHAM H.B. 1919: Some parasitic Protozoa found in South Africa - XVI. S. Afr. J. Sci. 16: 185-191.

FANTHAM H.B. 1930: Some parasitic Protozoa found in South Africa - XIII. S. Afr. J. Sci. 27: 376-390.
FOMENA A., BOUIX G. 1994: New Myxosporidea species (Myxozoa) from freshwater teleosts in southern Cameroon (Central Africa). J. Afr. Zool. 108: 481-491.

FOMENA A., BOUIX G. 1997: Myxosporea (Protozoa: Myxozoa) of the freshwater fishes in Africa: keys to the genera and species. Syst. Parasitol. 37: 161-178.

FOMENA A., BOUIX G., BIRGI É. 1985: Contribution à l'étude des Myxosporidies des poissons d'eau du Cameroun II. Espèces nouvelles du genre Myxobolus Bütschli, 1882. Bull. Inst. Fond. Afr. Noire 46: 167-192.

FOMENA A., MARQUÉS A., BOUIX G. 1993: Myxosporidea (Myxozoa) of Oreochromis niloticus (Linnaeus 1757) (Teleost: Cichlidae) in fish farming pools at Melen (Yaounde, Cameroon, Central Africa). J. Afr. Zool. 107: 45-56.

GILCHRIST J.D.F. 1924: A protozoal parasite Chloromyxum thyrsites sp. n. of the Cape sea fish, the "snoek" (Thyrsites atun, Euplin). Trans. R. Soc. S. Afr. 11: 263-273. 
GURLEY R.R. 1893: On the classification of the Myxosporidia, a group of protozoan parasites infesting fishes. Bull. U.S. Fish. Comm. 11: 407-431.

KOSTOÏNGUE B., TOGUEBAYE B.S. 1994: Le genre Myxobolus (Myxozoa, Myxosporea) chez poissons d'eau douce du Tchad avec la description de trois nouvelles espèces. Bull. Inst. Fond. Afr. Noire 47: 63-71.

LANDSBERG J.H. 1985: Myxosporean infections in cultured Tilapias in Israel. J. Protozool. 32: 194-201.

LOM J., ARTHUR J.R. 1989: A guideline for the preparation of species descriptions in Myxosporea. J. Fish Dis. 12: 151-156.

OBIEKEZIE A.I., OKAEME A.N. 1990: Myxosporea (Protozoa) infections of cultured Tilapias in Nigeria. J. Afr. Zool. 104: 77-91.

Received 9 July 2001
PAPERNA I., HARTLEY A.H., CROSS R. 1987: Ultrastructural studies on the plasmodium of Myxidium giardi (Myxosporea) and its attachment to the epithelium of the urinary bladder. Int. J. Parasitol. 17: 813-819.

PETERS H.M. 1971: Sporozoan cysts, the basis of purported "mouth-brooding" in the African labyrinthine fish, Ctenopoma multispinis (Pisces: Anabantidae). Am. Soc. Ichthyol. 1: 185.

SAKITI N., BLANC E., MARQUÉS A., BOUIX G. 1991: Myxosporidies (Myxozoa: Myxosporea) du genre Myxobolus Bütschli, 1882 parasites de poissons Cichlidae du lac Nokoué au Bénin (Afrique de l'Ouest). J. Afr. Zool. 105: $173-186$

Accepted 14 December 2001 